\title{
Process Design and Technoeconomic Assessment of the Extraction of Levulinic Acid from Biomass Hydrolysate Using $n$ - Butyl Acetate, Hexane, and 2-Methyltetrahydrofuran
}

Jean Felipe Leal Silva*, Rubens Maciel Filho, Maria Regina Wolf Maciel

School of Chemical Engineering, University of Campinas

500 Albert Einstein Av. (FEQ/UNICAMP), Campinas, São Paulo, Brazil

*jefelipe@outlook.com; jefelipe@feq.unicamp.br

\begin{abstract}
This document includes tables and figures that support the findings in the above-mentioned paper. Section 1 shows the ternary diagrams used to determine the ranges of operating conditions in the extractor. Table S1 (section 2) is interesting for readers trying to reproduce the simulation based on the process design included in the methodology of the primary research article (PRA). Figures S4 - S8 in section 3 provide the vapor-liquidliquid equilibria diagrams comparing results from our model to experimental data, which are mentioned in section 3.4.2 of the PRA. Section 4 describes in detail the analytical method of the experimental trial used to validate the liquid extraction process, and also includes Table $\mathrm{S} 3$, in which results of experimental trials using an extraction column from a reference were compared to results from our model. Section 5 includes Figures S9-S12, which are the equivalents of Figures 2 and 3 of the PRA but for the other two solvents. Lastly, section 6 provides tables with results of mass balance, steam requirement, and expenditures in each simulation case for all solvents (B01-B16, H01-H16, and M01-M16).
\end{abstract}

\section{Table of Contents}

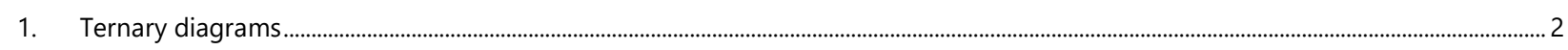

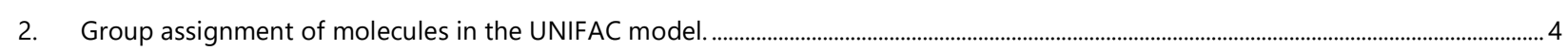

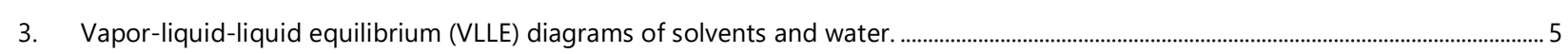

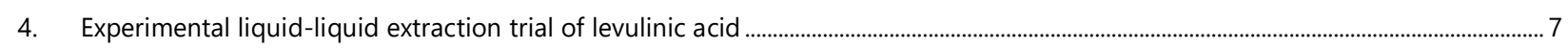

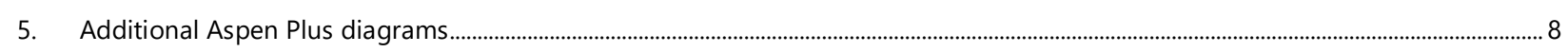

6. Detailed results of process simulation and economic evaluation ……................................................................................................ 11

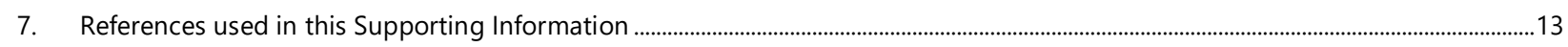




\section{Ternary diagrams}
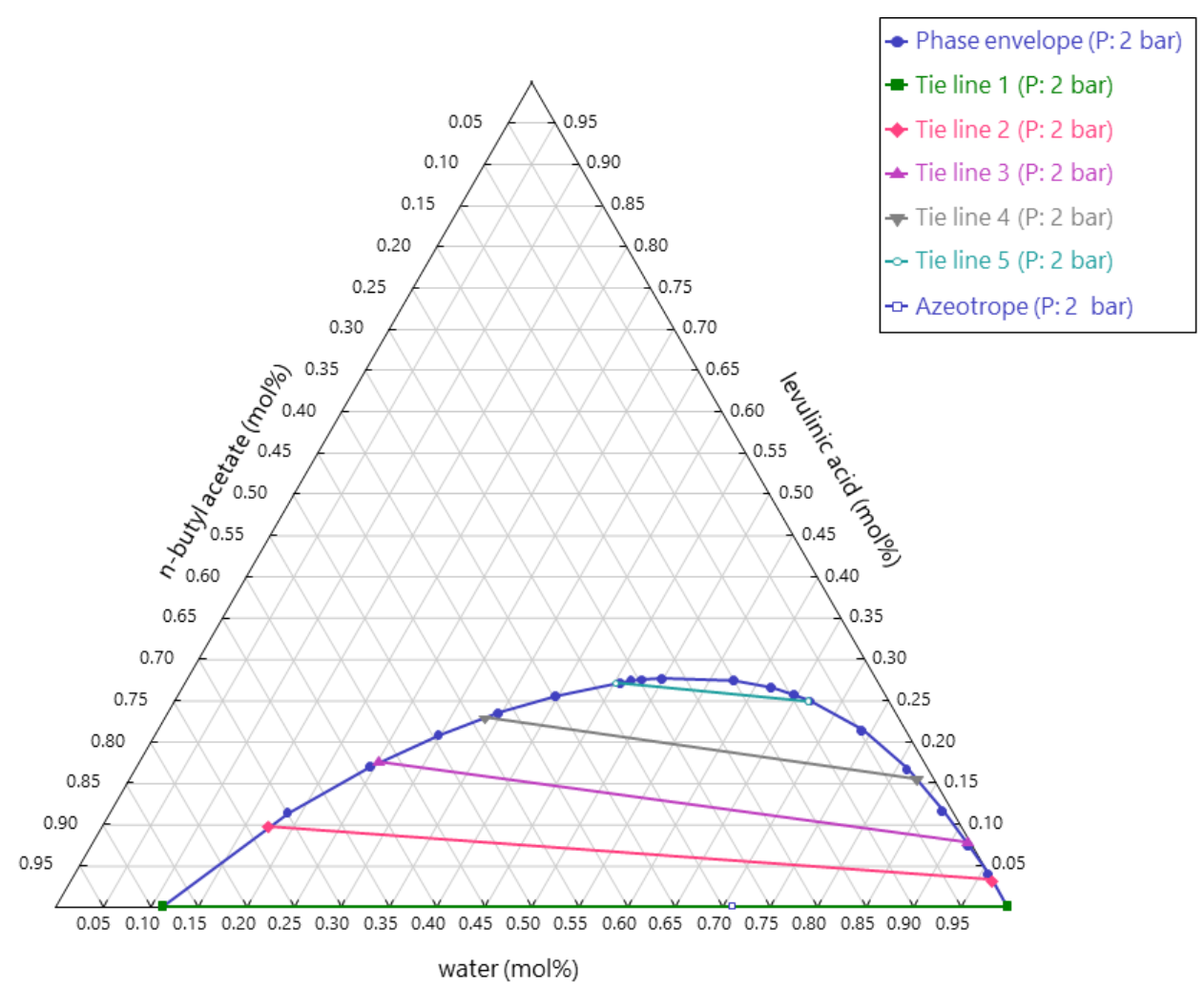

Figure S1. Ternary diagram of the system water + levulinic acid $+n$-butyl acetate $\left(70^{\circ} \mathrm{C}, 2\right.$ bar $)$.

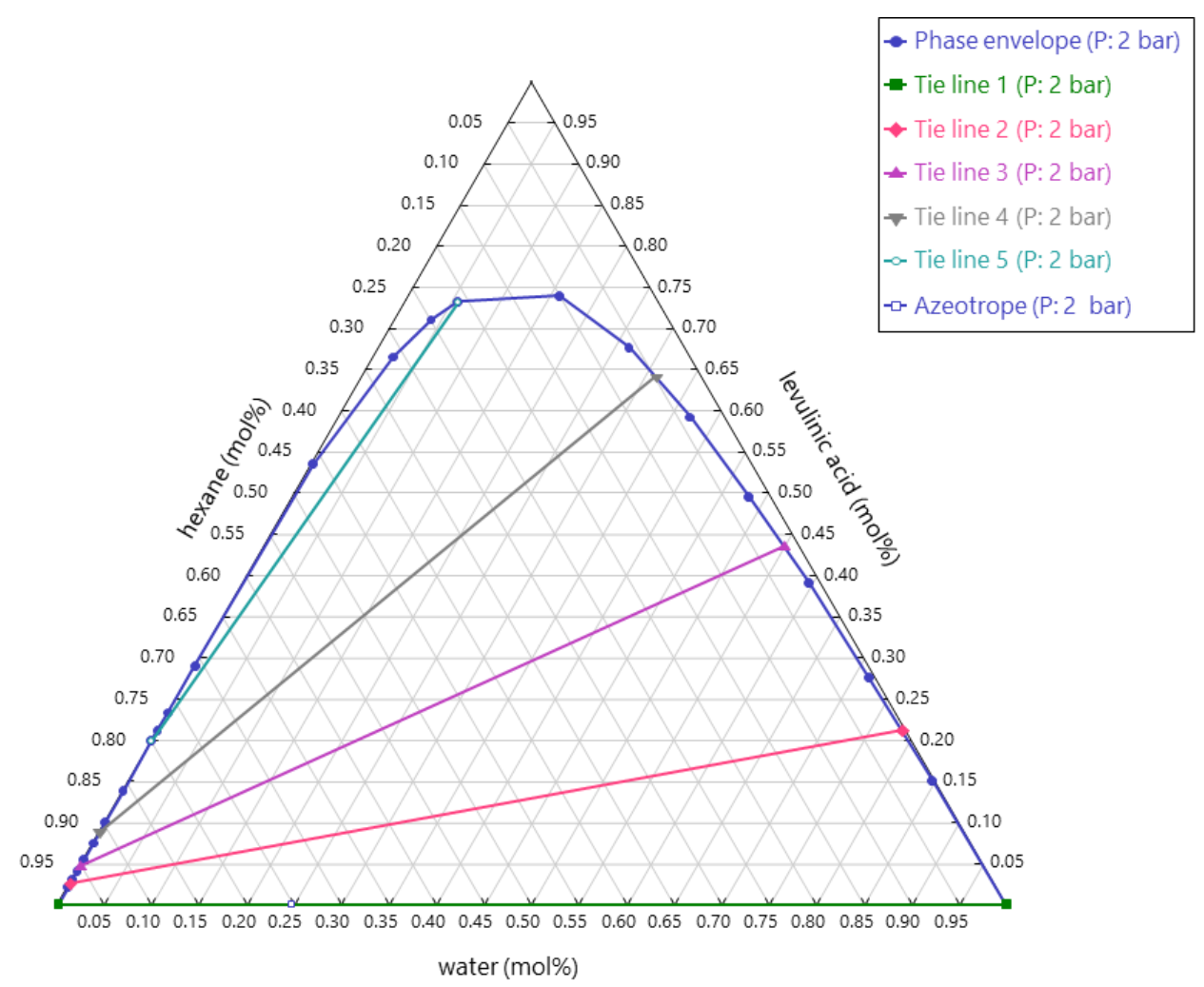

Figure S2. Ternary diagram of the system water + levulinic acid + hexane $\left(70^{\circ} \mathrm{C}, 2 \mathrm{bar}\right)$. 


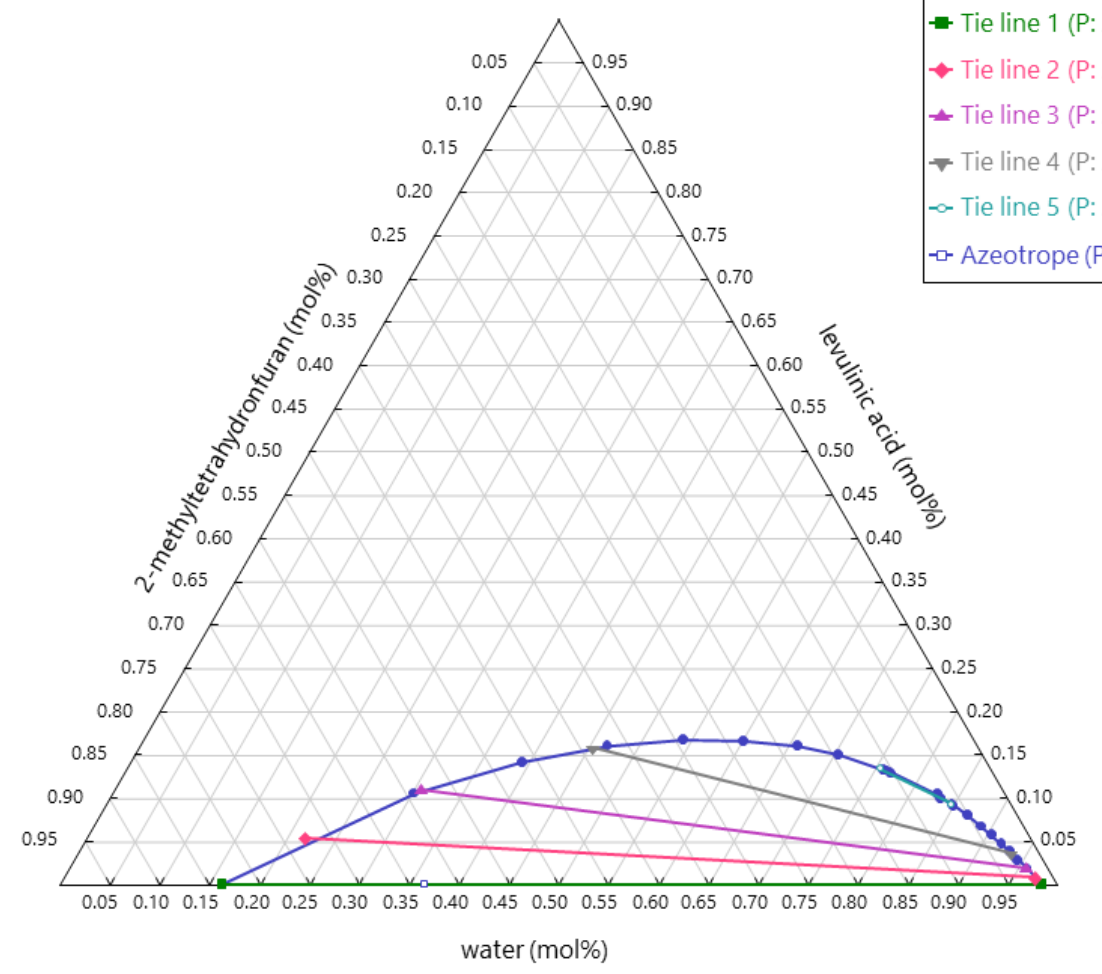

Figure S3. Ternary diagram of the system water + levulinic acid + 2-methyltetrahydrofuran $\left(70^{\circ} \mathrm{C}, 2\right.$ bar $)$. 


\section{Group assignment of molecules in the UNIFAC model.}

Table S1. Group assignment for each molecule in Aspen Plus 8.6, with group description based on UNIFAC nomenclature. ${ }^{1}$

\begin{tabular}{|c|c|c|}
\hline Molecule & Group number & Group description \\
\hline \multirow[t]{2}{*}{ Acetic acid } & $1 \times 1015$ & $\mathrm{CH}_{3}$ \\
\hline & $1 \times 1955$ & $\mathrm{COOH}$ \\
\hline \multirow{3}{*}{ n-Butyl acetate } & $1 \times 1015$ & $\mathrm{CH}_{3}$ \\
\hline & $3 \times 1010$ & $\mathrm{CH}_{2}$ \\
\hline & $1 \times 1505$ & $\mathrm{H}_{3} \mathrm{CCOO}$ \\
\hline Formic acid & $1 \times 1950$ & $\mathrm{HCOOH}$ \\
\hline Furfural & $1 \times 2450$ & FURFURAL \\
\hline \multirow[t]{2}{*}{ Hexane } & $4 \times 1010$ & $\mathrm{CH}_{2}$ \\
\hline & $2 \times 1015$ & $\mathrm{CH}_{3}$ \\
\hline \multirow[t]{4}{*}{ 2-MeTHF } & $1 \times 1005$ & $\mathrm{CH}$ \\
\hline & $2 \times 1010$ & $\mathrm{CH}_{2}$ \\
\hline & $1 \times 1015$ & $\mathrm{CH}_{3}$ \\
\hline & $1 \times 1600$ & $\mathrm{FCH}_{2} \mathrm{O}^{\mathrm{a}}$ \\
\hline \multirow[t]{3}{*}{ Levulinic acid } & $2 \times 1010$ & $\mathrm{CH}_{2}$ \\
\hline & $1 \times 1405$ & $\mathrm{CH}_{3} \mathrm{CO}$ \\
\hline & $1 \times 1955$ & $\mathrm{COOH}$ \\
\hline Water & $1 \times 1300$ & $\mathrm{H}_{2} \mathrm{O}$ \\
\hline
\end{tabular}

a) $\mathrm{F}$ denotes $-\mathrm{CH}_{2} \mathrm{O}$ - in a furan ring 
3. Vapor-liquid-liquid equilibrium (VLLE) diagrams of solvents and water.

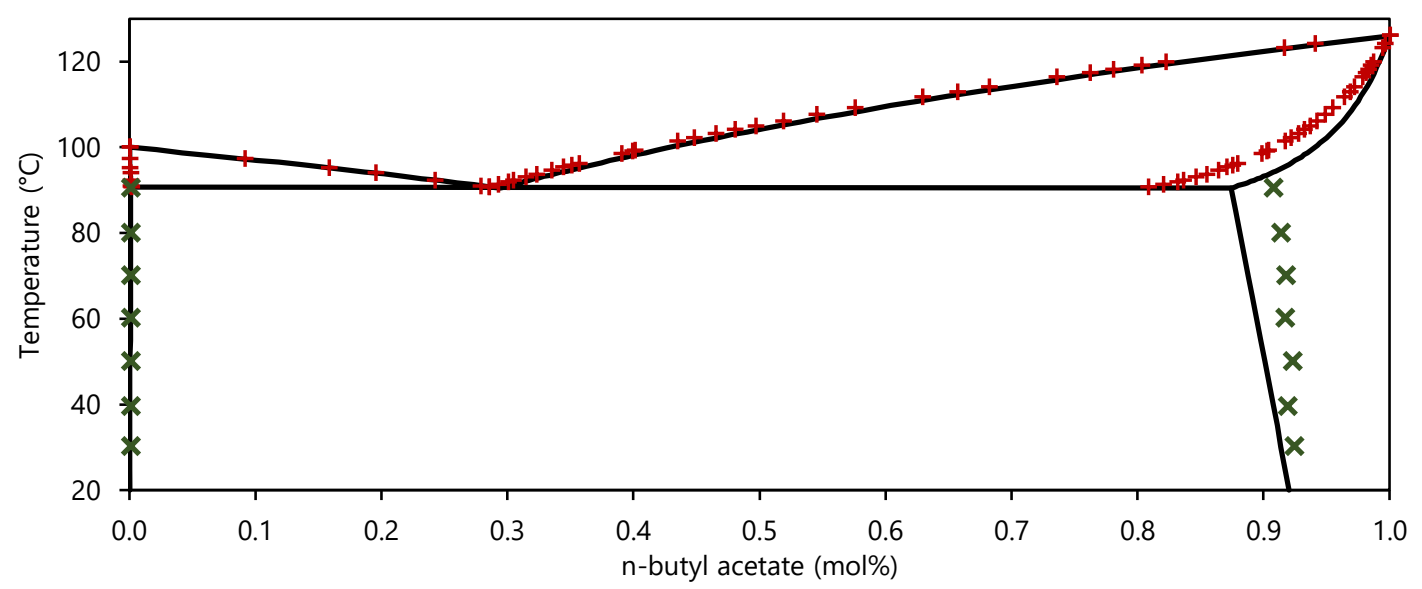

Figure S4. VLLE diagram of n-butyl acetate+water at 1 atm. (-) Calculated using the thermodynamic modeling described in the paper, (x) data from Stephenson et al. (1986), ${ }^{2}$ and (+) data from Cho et al. (1983). ${ }^{3}$

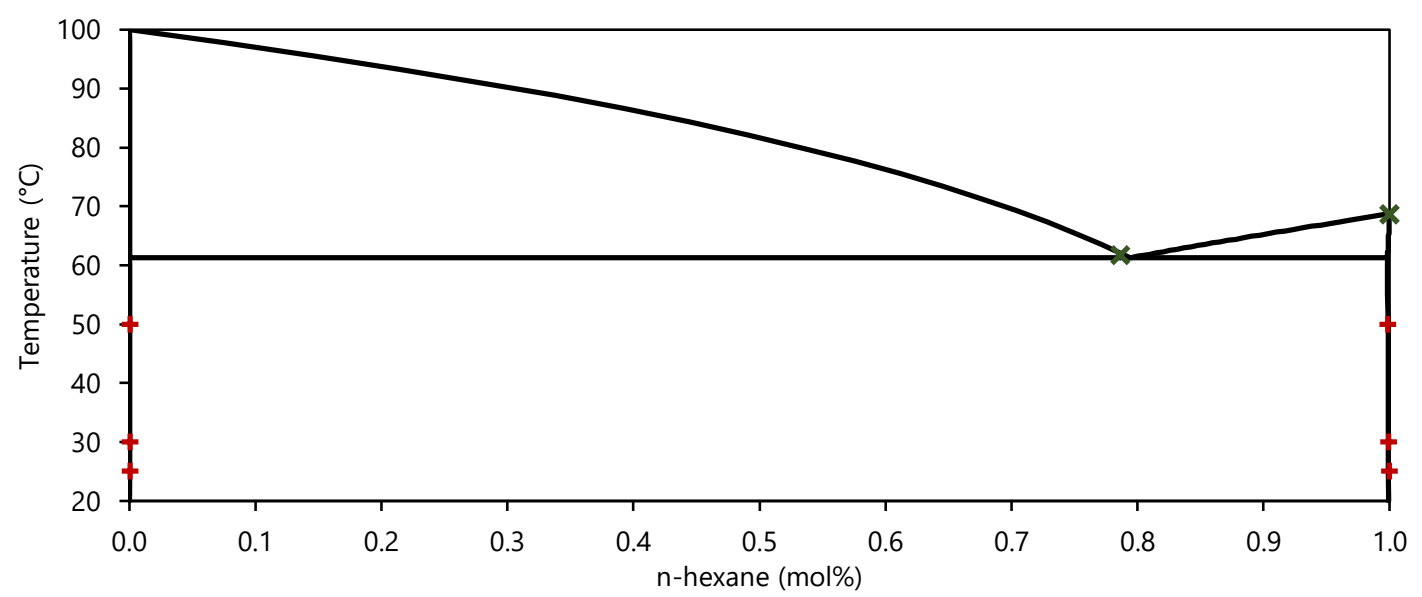

Figure S5. VLLE diagram of hexane+water at $1 \mathrm{~atm}$. (-) Calculated using the thermodynamic modeling described in the paper, (x) data from Ikari et al. (1991), ${ }^{4}$ and (+) data from Razzouk et al. (2010). ${ }^{5}$

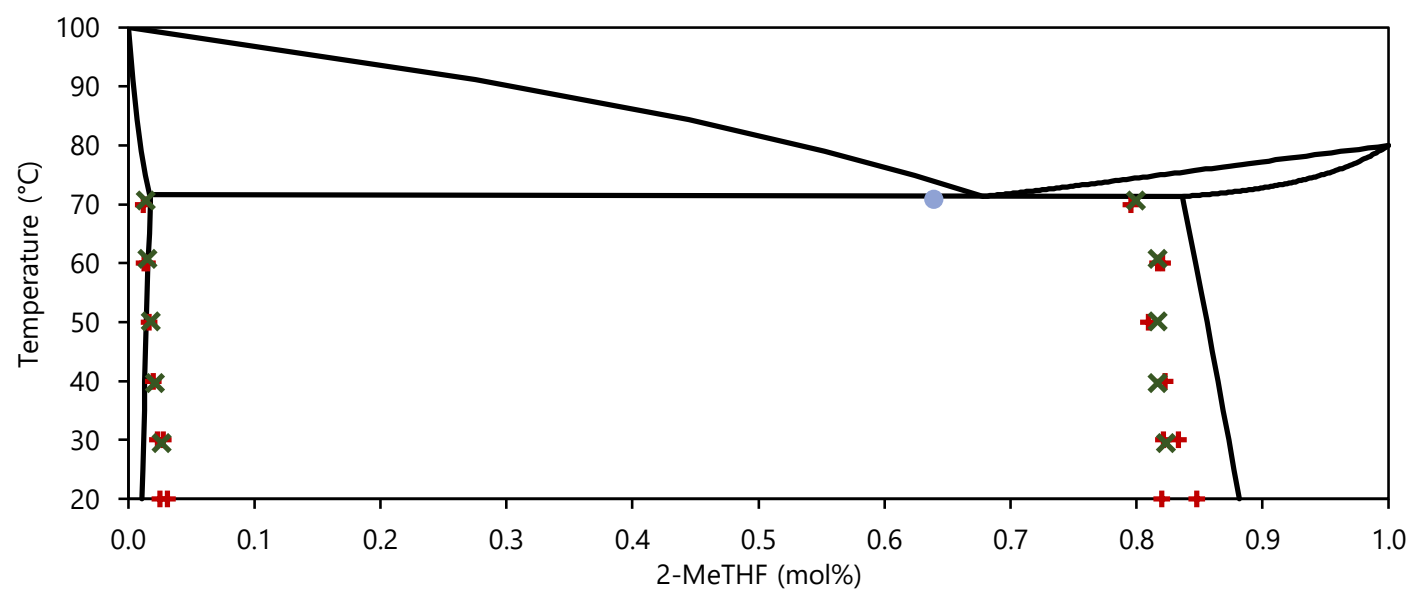

Figure S6. VLLE diagram of 2-MeTHF+water at $1 \mathrm{~atm}$. (-) Calculated using the thermodynamic modeling described in the paper, (x) data from Stephenson et al. (1992), ${ }^{6}(\cdot)$ data from Hangx et al. (2014), ${ }^{7}$ and (+) data from Glass et al. (2017). ${ }^{8}$ No literature data is available for the vapor phase, except for the azeotrope ( $)$. 


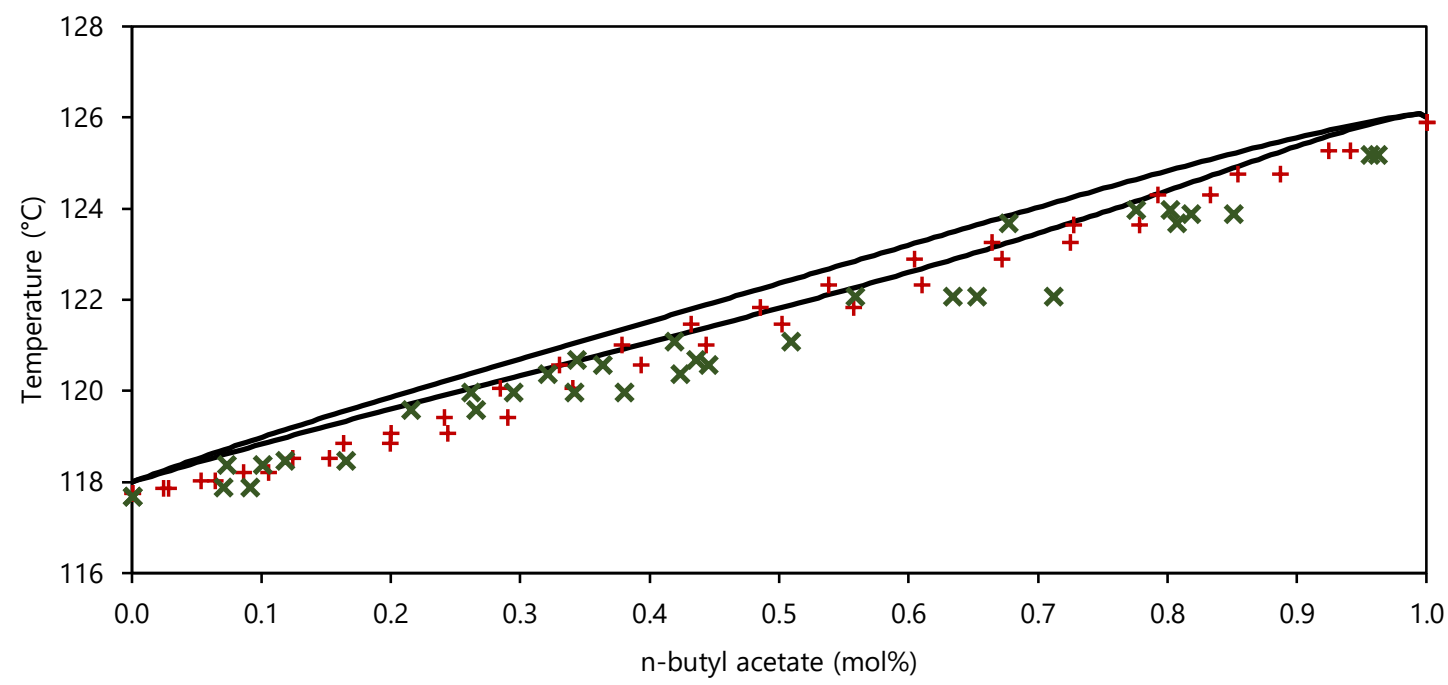

Figure S7. VLE diagram of n-butyl acetate+acetic acid at 1 atm. (-) Calculated using the thermodynamic modeling described in the paper, (x) data from Hirata et al. (1966) ${ }^{9}$ and (+) data from Lladosa et al. (2008). ${ }^{10}$

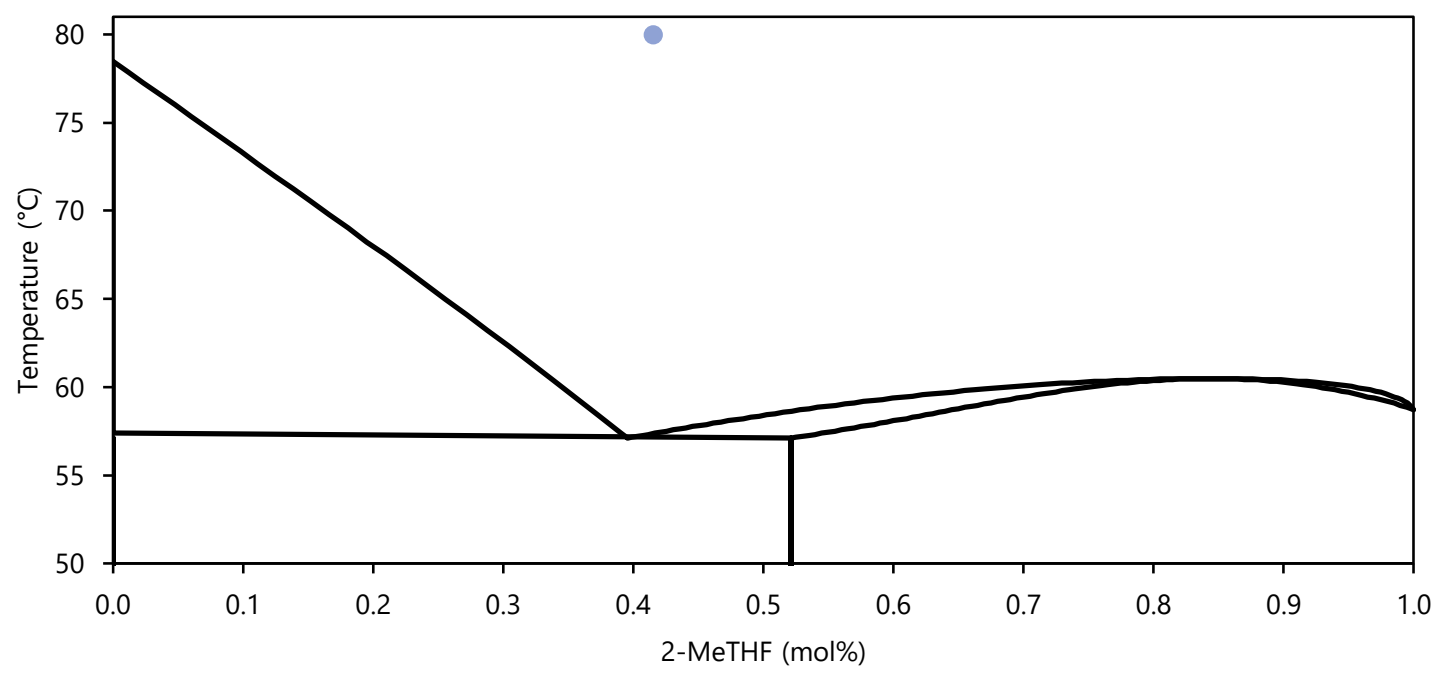

Figure S8. VLLE diagram of 2-MeTHF + formic acid at 0.5 bar. (-) Calculated using the thermodynamic modeling described in the paper. No literature data is available except for the azeotrope (०), which represents data from Hangx et al. (2014). ${ }^{7}$

Figure S8 demonstrates a substantial disagreement between experimental data available in the patent by Hangx et al. (2014). ${ }^{7}$ and the developed thermodynamic model for the binary mixture 2-MeTHF+formic acid. According to this result, the model presents a shortcoming to calculate the liquid activity coefficient for formic acid. Nevertheless, according to batch distillation results from Hangx et al. (2014), ${ }^{7}$ the distillation of 2-MeTHF and formic acid in the presence of water proceeds to recover 2-MeTHF in the distillate and formic acid in the bottom, with a split of water between top and bottom because of the azeotropes of light key and heavy key components with water. This same behavior was simulated using the model with similar concentrations for the first and last fractions. This result indicated that, even though our model cannot correctly predict the experimental azeotrope composition, this problem does not compromise the final composition of top and bottom products. Moreover, formic acid is produced at a very low rate in this process (section 5 of this Supporting Information). Therefore, based on its price, inaccuracies in its recovery have low impact in the RC. Regarding inaccuracies in the operation of the distillation column, an increase of $20 \%$ in the energy requirements (both condenser and reboiler) of C-01 would increase the RC of case $\mathrm{M} 16$ by only $2.4 \%$. 


\section{Experimental liquid-liquid extraction trial of levulinic acid}

$20.801 \mathrm{~g}$ of 2-MeTHF (Sigma-Aldrich, purity of $99.9 \mathrm{wt} \%$ ) were added to $9.905 \mathrm{~g}$ of a solution of $30 \mathrm{wt} \%$ of levulinic acid (SigmaAldrich, purified to $99.899 \mathrm{wt} \%$ ), which was prepared with ultrapure water (type I, filter Megapurity, Brazil, resistivity $<18.2 \mathrm{M} \Omega . \mathrm{cm}$ ). The mixture was stirred for $2 \mathrm{~h}$ and left to settle overnight on a closed equilibrium cell at $70{ }^{\circ} \mathrm{C}$ (temperature controlled to \pm 0.1 with a thermostatic bath Marconi MA 108/9 - Marconi, Brazil). Concentrations of 2-MeTHF and levulinic acid were determined using a diode array detector coupled to an HPLC system (Agilent 1260 Infinity II). In the method developed in our laboratory, the analytes elute through an Agilent Poroshell $120 \mathrm{EC}-184.6 \times 50 \mathrm{~mm} 2.7 \mu \mathrm{m}$ (Agilent, USA), using a mobile phase with $5 \mathrm{mmol} \mathrm{L}^{-1} \mathrm{H}_{2} \mathrm{SO}_{4}$ in aqueous solution with $15 \% \mathrm{MeCN}$ (Sigma-Aldrich, HPLC grade) by volume (type I water is added to complete final volume). All analytes elute in less than $2.3 \mathrm{~min}$ with a flow rate of $2 \mathrm{~mL} \mathrm{~min}^{-1}$. The detector measured absorbance at $\lambda=194 \mathrm{~nm}$ to detect 2-MeTHF (just above the cutoff for both water and $\mathrm{MeCN}$ ). Triplicates of each phase were diluted on a weight basis using mobile phase. Vials with samples were weighed in a XP205DR (Mettler Toledo, Switzerland, uncertainty of $0.01 \mathrm{mg}$ ). Mass fraction of water was determined as the fraction remaining to 1.

Table S2. Results of mass fraction of components in each phase.

\begin{tabular}{llll}
\hline & 2-MeTHF & levulinic acid & water \\
\hline Phase 1 & 0.8257 & 0.1065 & 0.0678 \\
Phase 2 & 0.0758 & 0.0576 & 0.8666 \\
\hline
\end{tabular}

From these concentrations and the initial composition of the feed, a simple mass balance shows that $2.620 \mathrm{~g}$ of levulinic acid were recovered in phase 1 (recovery: 88.17\%). Using the same feed as input in Aspen Plus and using the same thermodynamic model described in the methodology of this work, $2.613 \mathrm{~g}$ of levulinic acid are recovered in phase 1 (recovery: $87.94 \%$ ). Therefore, the actual recovery is only $0.26 \%$ larger than the recovery estimated using the thermodynamic model described in this work.

The extractor model was also validated based on experimental data. For each run indicated in Table S3, a different extractor was simulated based on the number of transfer units and mass of solvent and feed reported in the reference. Recovered levulinic acid in the reference was calculated via mass balance based on the mass of feed and solvent fed to the column and the concentration of levulinic acid in feed, raffinate and extract streams.

Table S3. Comparison of experimental data to model results of Laitinen et al (2016). ${ }^{11}$

\begin{tabular}{lllllllll}
\hline Run & S/F & $\begin{array}{l}\text { Rotor speed } \\
(\mathrm{rpm})\end{array}$ & $\begin{array}{l}\text { Levulinic acid, } \\
\text { feed }(\mathrm{kg})\end{array}$ & $\begin{array}{l}\text { Levulinic acid in extract, } \\
\text { experimental }(\mathrm{kg})\end{array}$ & $\begin{array}{l}\text { Levulinic acid in } \\
\text { extract, model }(\mathrm{kg})\end{array}$ & $\begin{array}{l}\text { Recovery, } \\
\text { experimental }\end{array}$ & $\begin{array}{l}\text { Recovery, } \\
\text { model }\end{array}$ & \begin{tabular}{l} 
Efficiency \\
\hline 1
\end{tabular} \\
\hline 0.75 & 100 & 0.206 & 0.197 & 0.201 & $95.49 \%$ & $97.72 \%$ & $97.72 \%$ \\
2 & 0.80 & 125 & 0.217 & 0.212 & 0.215 & $97.73 \%$ & $98.76 \%$ & $98.96 \%$ \\
3 & 0.73 & 150 & 0.204 & 0.194 & 0.202 & $95.24 \%$ & $98.97 \%$ & $96.23 \%$ \\
4 & 0.89 & 100 & 0.499 & 0.492 & 0.492 & $98.62 \%$ & $98.56 \%$ & $100.07 \%$ \\
5 & 0.90 & 125 & 0.512 & 0.507 & 0.508 & $99.02 \%$ & $99.22 \%$ & $99.80 \%$ \\
6 & 0.79 & 150 & 0.502 & 0.500 & 0.501 & $99.61 \%$ & $99.76 \%$ & $99.85 \%$ \\
7 & 0.79 & 100 & 0.730 & 0.712 & 0.719 & $97.46 \%$ & $98.45 \%$ & $98.99 \%$ \\
8 & 0.95 & 125 & 0.720 & 0.719 & 0.720 & $99.80 \%$ & $99.95 \%$ & $99.85 \%$ \\
9 & 0.87 & 125 & 0.725 & 0.724 & 0.725 & $99.81 \%$ & $99.94 \%$ & $99.87 \%$ \\
\hline
\end{tabular}




\section{Additional Aspen Plus diagrams}

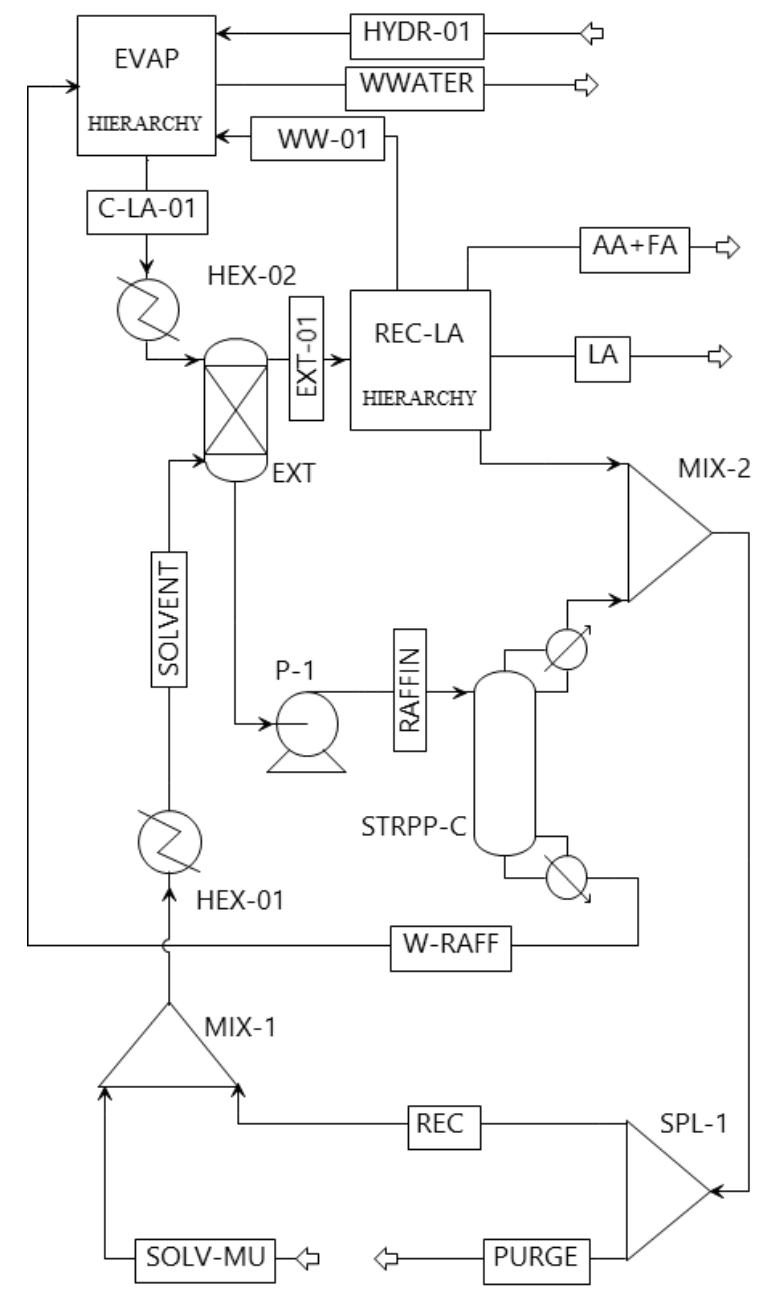

Figure 59. Extraction process in the case of $n$-butyl acetate as solvent. 


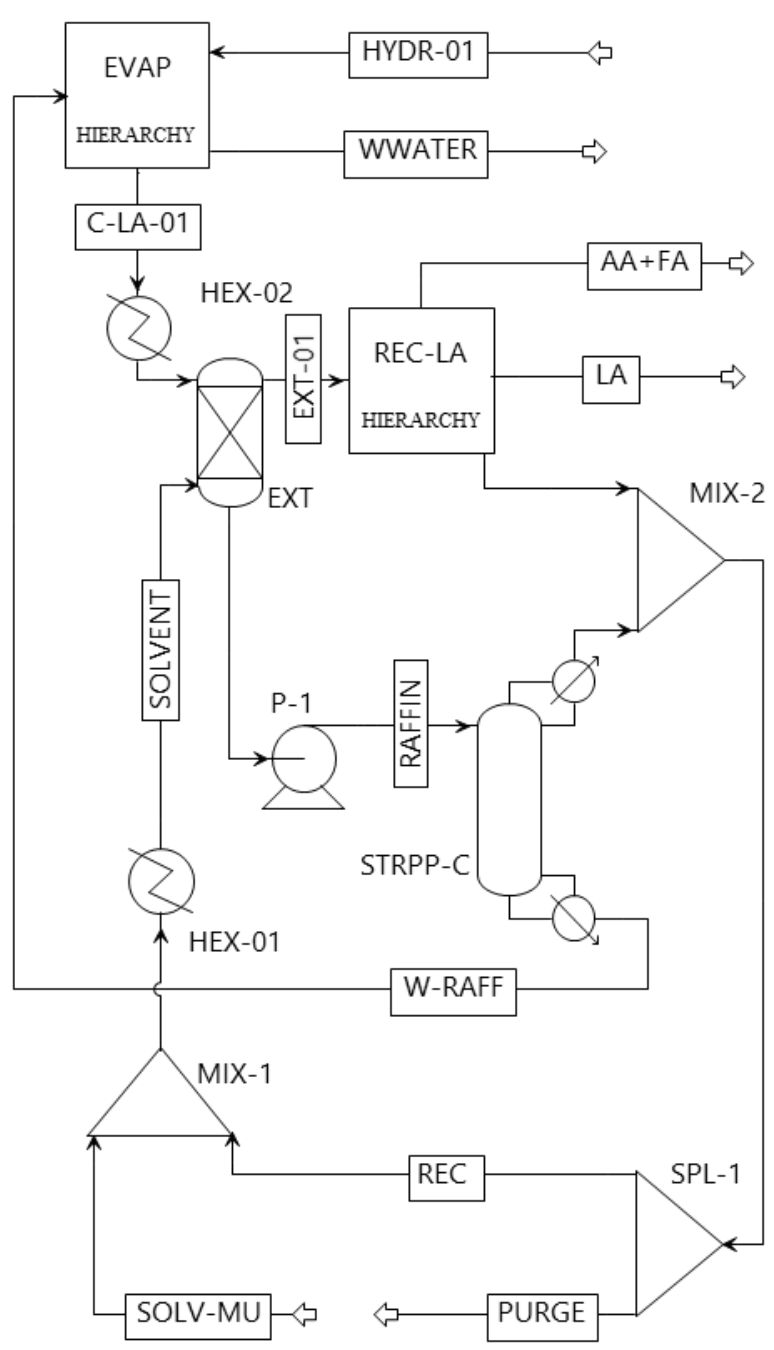

Figure S10. Extraction process in the case of hexane as solvent.

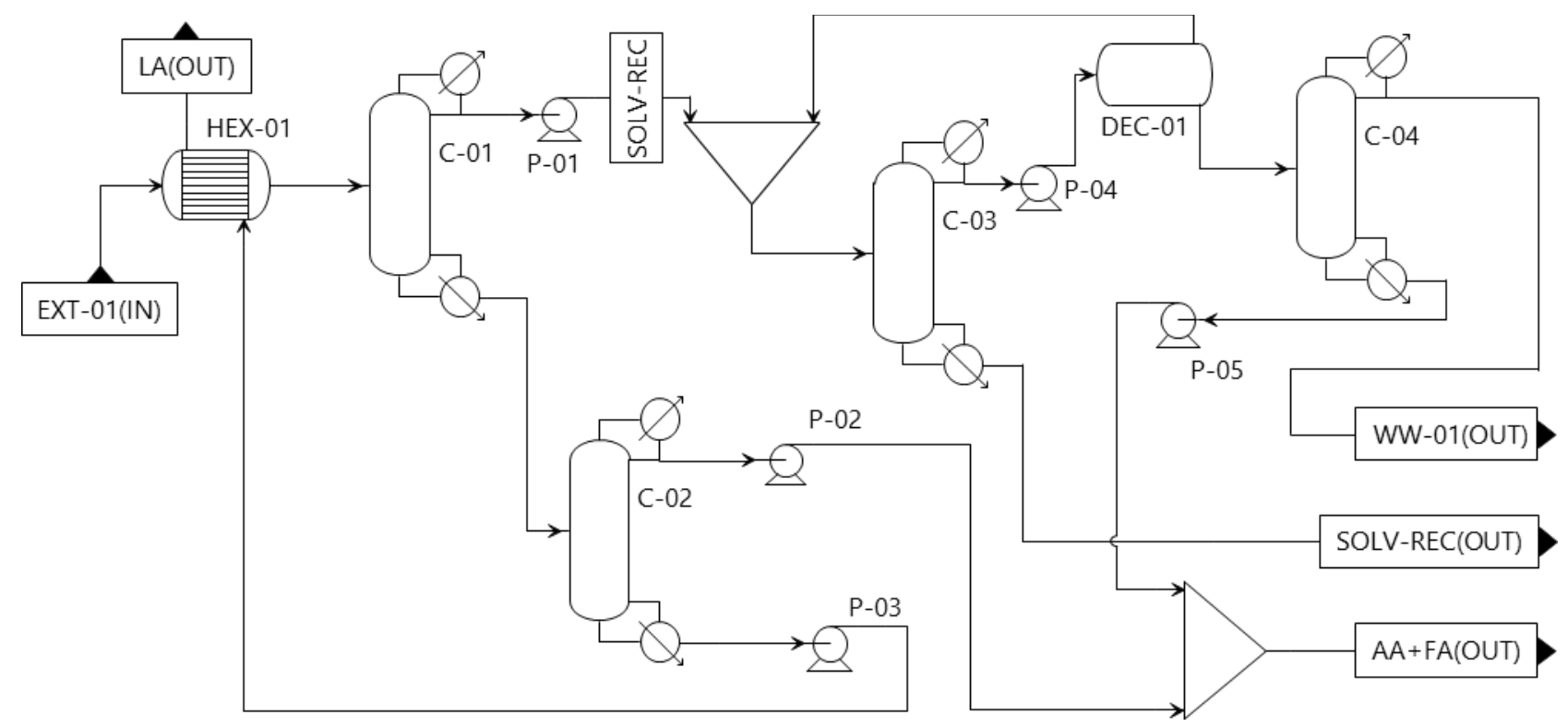

Figure S11. Recovery of n-butyl acetate, levulinic acid, and light carboxylic acids (acetic acid and formic acid). C-03 and C-04 work as a pair of azeotropic columns. 


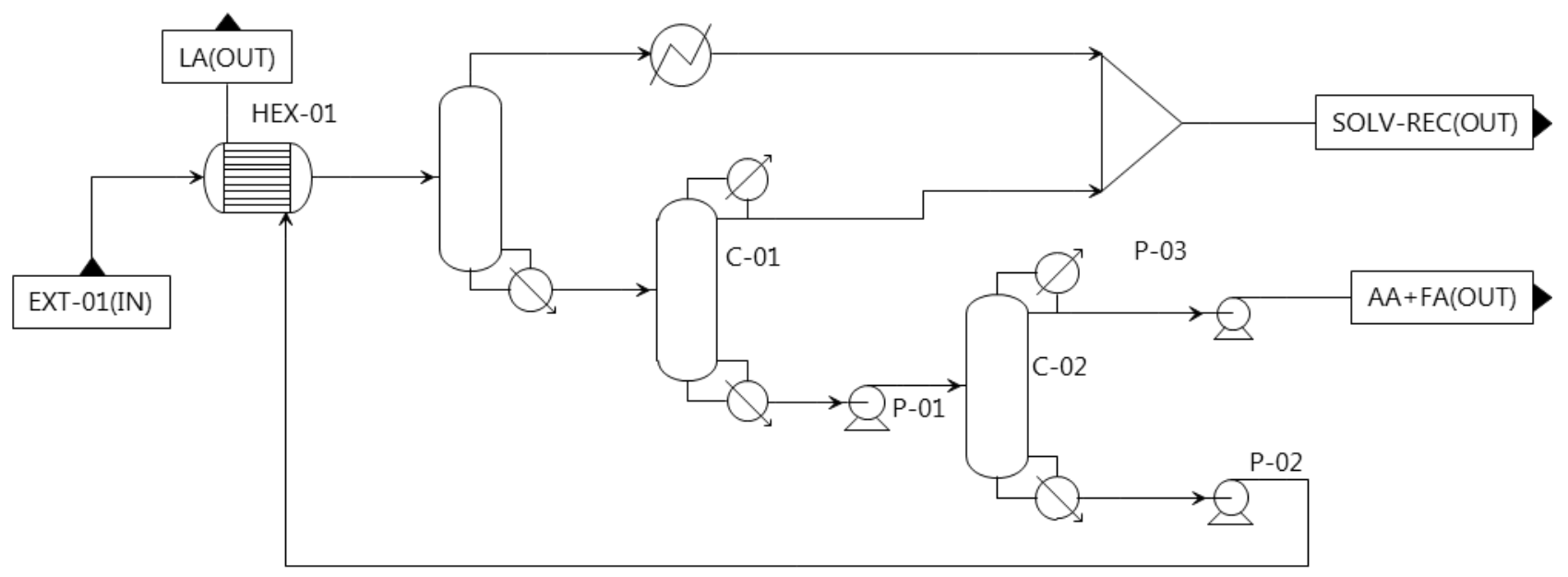

Figure S12. Recovery of hexane, levulinic acid, and light carboxylic acids (acetic acid and formic acid). The first column is used to recover most of the hexane with no need of reflux. 


\section{Detailed results of process simulation and economic evaluation}

Table S4. Detailed results of process simulation and economic assessment of the cases of the design of experiments considering $n$-butyl acetate as extraction solvent (cases B01 to B16).

\begin{tabular}{lllllllll}
\hline Case & $\begin{array}{l}\text { LA } \\
\left(\mathrm{kg} \mathrm{h}^{-1}\right)^{\mathrm{a}}\end{array}$ & $\begin{array}{l}\text { AA+FA } \\
\left(\mathrm{kg} \mathrm{h}^{-1}\right)^{\mathrm{b}}\end{array}$ & $\begin{array}{l}\mathrm{n} \text {-Butyl acetate } \\
\left(\mathrm{kg} \mathrm{h}^{-1}\right)\end{array}$ & $\begin{array}{l}\text { Steam demand } \\
\left(\mathrm{kg} \mathrm{kg}^{-1}\right)\end{array}$ & $\begin{array}{l}\text { CAPEX } \\
\left(10^{6} \$\right)\end{array}$ & $\begin{array}{l}\text { OPEX } \\
\left(10^{6} \$ \mathrm{y}^{-1}\right)\end{array}$ & $\begin{array}{l}\text { Revenue } \\
\left(10^{6} \$ \mathrm{y}^{-1}\right)\end{array}$ & $\begin{array}{l}\mathrm{RC} \\
\left(\$ \mathrm{~kg}^{-1}\right)\end{array}$ \\
\hline B01 & 16499 & 1397 & 1074 & 19.2 & 14.9 & 29.1 & 3.5 & 0.353 \\
B02 & 16507 & 859 & 541 & 15.4 & 12.7 & 22.2 & 2.2 & 0.279 \\
B03 & 15279 & 603 & 200 & 16.4 & 12.3 & 19.1 & 1.5 & 0.267 \\
B04 & 15276 & 566 & 151 & 16.2 & 12.1 & 18.6 & 1.4 & 0.261 \\
B05 & 16855 & 1579 & 1117 & 17.0 & 15.1 & 27.3 & 4.0 & 0.319 \\
B06 & 16826 & 1164 & 493 & 13.7 & 12.8 & 19.9 & 2.9 & 0.236 \\
B07 & 16675 & 881 & 233 & 11.7 & 13.5 & 15.8 & 2.2 & 0.198 \\
B08 & 16670 & 838 & 205 & 11.6 & 13.3 & 15.5 & 2.1 & 0.194 \\
B09 & 15717 & 658 & 280 & 16.1 & 11.3 & 19.8 & 1.6 & 0.264 \\
B10 & 16748 & 926 & 336 & 11.9 & 12.4 & 16.7 & 2.3 & 0.204 \\
B11 & 16494 & 1009 & 677 & 16.0 & 12.5 & 22.8 & 2.5 & 0.282 \\
B12 & 16075 & 663 & 160 & 13.4 & 14.4 & 16.6 & 1.7 & 0.224 \\
B13 & 16221 & 970 & 415 & 14.6 & 12.9 & 19.6 & 2.4 & 0.248 \\
B14 & 16276 & 735 & 276 & 13.7 & 12.0 & 17.7 & 1.8 & 0.229 \\
B15 & 16271 & 781 & 312 & 13.8 & 12.1 & 18.1 & 2.0 & 0.232 \\
B16 & 16692 & 761 & 166 & 11.3 & 12.8 & 14.9 & 1.9 & 0.189 \\
\hline
\end{tabular}

a) Stream containing recovered levulinic acid, purity $>99.5 \mathrm{wt} \%$.

b) Stream containing mixture of recovered light carboxylic acids (acetic and formic acids).

Table S5. Detailed results of process simulation and economic assessment of the cases of the design of experiments considering hexane as extraction solvent (cases $\mathrm{H} 01$ to H16).

\begin{tabular}{lllllllll}
\hline Case & $\begin{array}{l}\text { LA } \\
\left(\mathrm{kg} \mathrm{h}^{-1}\right)^{\mathrm{a}}\end{array}$ & $\begin{array}{l}\text { AA+FA } \\
\left(\mathrm{kg} \mathrm{h}^{-1}\right)^{\mathrm{b}}\end{array}$ & $\begin{array}{l}\text { Hexane } \\
\left(\mathrm{kg} \mathrm{h}^{-1}\right)\end{array}$ & $\begin{array}{l}\text { Steam demand } \\
\left(\mathrm{kg} \mathrm{kg}^{-1}\right)\end{array}$ & $\begin{array}{l}\text { CAPEX } \\
\left(10^{6} \$\right)\end{array}$ & $\begin{array}{l}\text { OPEX } \\
\left(10^{6} \$ \mathrm{y}^{-1}\right)\end{array}$ & $\begin{array}{l}\text { Revenue } \\
\left(10^{6} \$ \mathrm{y}^{-1}\right)\end{array}$ & $\begin{array}{l}\text { RC } \\
\left(\$ \mathrm{~kg}^{-1}\right)\end{array}$ \\
\hline H01 & 15573 & 499 & 3591 & 21.1 & 17.7 & 32.5 & 1.2 & 0.457 \\
H02 & 15621 & 479 & 2976 & 19.7 & 16.4 & 29.3 & 1.2 & 0.411 \\
H03 & 13758 & 201 & 1189 & 18.5 & 13.9 & 20.0 & 0.5 & 0.330 \\
H04 & 13763 & 189 & 974 & 17.9 & 13.3 & 18.9 & 0.5 & 0.311 \\
H05 & 16710 & 580 & 3848 & 16.7 & 19.5 & 30.4 & 1.5 & 0.401 \\
H06 & 16604 & 672 & 3190 & 15.5 & 17.9 & 27.1 & 1.7 & 0.355 \\
H07 & 16311 & 358 & 1432 & 12.3 & 16.0 & 17.8 & 0.9 & 0.249 \\
H08 & 16319 & 334 & 1134 & 11.8 & 15.4 & 16.3 & 0.8 & 0.229 \\
H09 & 15092 & 494 & 2129 & 18.6 & 15.3 & 24.9 & 1.2 & 0.361 \\
H10 & 16526 & 655 & 2376 & 13.8 & 16.8 & 22.7 & 1.6 & 0.300 \\
H11 & 16214 & 661 & 3248 & 17.1 & 16.9 & 28.5 & 1.7 & 0.380 \\
H12 & 15199 & 299 & 1122 & 14.2 & 13.9 & 17.7 & 0.7 & 0.263 \\
H13 & 15996 & 549 & 2557 & 16.2 & 16.5 & 25.1 & 1.4 & 0.344 \\
H14 & 15975 & 541 & 2300 & 15.7 & 15.9 & 23.7 & 1.4 & 0.325 \\
H15 & 15975 & 540 & 2313 & 15.7 & 16.0 & 23.8 & 1.4 & 0.327 \\
H16 & 16318 & 335 & 1137 & 11.8 & 14.9 & 16.3 & 0.8 & 0.229 \\
\hline
\end{tabular}

a) Stream containing recovered levulinic acid, purity $>99.5 \mathrm{wt} \%$.

b) Stream containing mixture of recovered light carboxylic acids (acetic and formic acids). 
Table S6. Detailed results of process simulation and economic assessment of the cases of the design of experiments considering 2methyltetrahydrofuran as extraction solvent (cases M01 to M16).

\begin{tabular}{lllllllll}
\hline Case & $\begin{array}{l}\text { LA } \\
\left(\mathrm{kg} \mathrm{h}^{-1}\right)^{\mathrm{a}}\end{array}$ & $\begin{array}{l}\text { AA+FA } \\
\left(\mathrm{kg} \mathrm{h}^{-1}\right)^{\mathrm{b}}\end{array}$ & $\begin{array}{l}\text { MTHF } \\
\left(\mathrm{kg} \mathrm{h}^{-1}\right)\end{array}$ & $\begin{array}{l}\text { Steam demand } \\
\left(\mathrm{kg} \mathrm{kg}^{-1}\right)\end{array}$ & $\begin{array}{l}\text { CAPEX } \\
\left(10^{6} \$\right)\end{array}$ & $\begin{array}{l}\text { OPEX } \\
\left(10^{6} \$ \mathrm{y}^{-1}\right)\end{array}$ & $\begin{array}{l}\text { Revenue } \\
\left(10^{6} \$ \mathrm{y}^{-1}\right)\end{array}$ & $\begin{array}{l}\text { RC } \\
\left(\$ \mathrm{~kg}^{-1}\right)\end{array}$ \\
\hline M01 & 16246 & 637 & 671 & 18.0 & 14.1 & 21.2 & 1.6 & 0.280 \\
M02 & 16469 & 389 & 304 & 15.3 & 11.5 & 16.9 & 1.0 & 0.226 \\
M03 & 15884 & 472 & 176 & 15.3 & 11.6 & 16.0 & 1.2 & 0.220 \\
M04 & 15983 & 618 & 66 & 15.5 & 11.2 & 16.0 & 1.5 & 0.213 \\
M05 & 16963 & 834 & 697 & 14.1 & 14.6 & 18.2 & 2.1 & 0.227 \\
M06 & 17058 & 454 & 316 & 11.7 & 12.5 & 13.9 & 1.1 & 0.181 \\
M07 & 16774 & 648 & 187 & 11.3 & 12.4 & 13.0 & 1.6 & 0.166 \\
M08 & 16860 & 893 & 68 & 11.6 & 12.2 & 13.1 & 2.2 & 0.158 \\
M09 & 16117 & 409 & 174 & 15.1 & 11.1 & 16.0 & 1.0 & 0.216 \\
M10 & 16864 & 527 & 183 & 11.2 & 11.9 & 12.9 & 1.3 & 0.166 \\
M11 & 16601 & 499 & 474 & 13.9 & 12.6 & 16.4 & 1.2 & 0.216 \\
M12 & 16343 & 643 & 78 & 12.9 & 11.6 & 13.9 & 1.6 & 0.181 \\
M13 & 16479 & 645 & 338 & 13.7 & 12.4 & 15.8 & 1.6 & 0.204 \\
M14 & 16513 & 455 & 143 & 12.8 & 11.3 & 13.9 & 1.1 & 0.185 \\
M15 & 16786 & 362 & 179 & 12.7 & 11.5 & 14.1 & 0.9 & 0.187 \\
M16 & 16846 & 697 & 85 & 11.0 & 11.9 & 12.4 & 1.7 & 0.156 \\
\hline
\end{tabular}

a) Stream containing recovered levulinic acid, purity $>99.5 \mathrm{wt} \%$.

b) Stream containing mixture of recovered light carboxylic acids (acetic and formic acids). 


\section{References used in this Supporting Information}

(1) Magnussen, T.; Rasmussen, P.; Fredenslund, A. UNIFAC Parameter Table for Prediction of Liquid-Liquid Equilibriums. Ind. Eng. Chem. Process Des. Dev. 1981, 20 (2), 331-339. https://doi.org/10.1021/i200013a024.

(2) Stephenson, R.; Stuart, J. Mutual Binary Solubilities: Water-Alcohols and Water-Esters. J. Chem. Eng. Data 1986, 31 (1), $56-70$. https://doi.org/10.1021/je00043a019.

(3) Cho, T. H.; Ochi, K.; Kojima, K. Measurement of Vapor-Liquid Equilibrium for Systems with Limited Miscibility. Fluid Phase Equilib. 1983, 11 (2), 137-152. https://doi.org/10.1016/0378-3812(83)80054-5.

(4) Ikari, A.; Hatate, Y.; Hosoda, K.; Kawabata, Y. Vapor-Liquid Equilibria of Hexane-Acetic Acid System and Hexane-Ethanol System Containing a Minute Amount of Water. KAGAKU KOGAKU RONBUNSHU 1991, 17 (4), $890-894$. https://doi.org/10.1252/kakoronbunshu.17.890.

(5) Razzouk, A.; Naccoul, R. A.; Mokbel, I.; Duchet-Suchaux, P.; Jose, J.; Rauzy, E.; Berro, C. Liquid-Liquid Equilibria for Monoethylene Glycol + Hexane and 2,2,4-Trimethylpentane, Water + Hexane and 2,2,4-Trimethylpentane, Monoethylene Glycol + Water + Hexane, and Monoethylene Glycol + Water + 2,2,4-Trimethylpentane in the Temperature Range between $T=283.15 \mathrm{~K}$ and $T=$ 323.15 K. J. Chem. Eng. Data 2010, 55 (4), 1468-1472. https://doi.org/10.1021/je900295u.

(6) Stephenson, R. M. Mutual Solubilities: Water-Ketones, Water-Ethers, and Water-Gasoline-Alcohols. J. Chem. Eng. Data 1992, 37 (1), 80-95. https://doi.org/10.1021/je00005a024.

(7) Hangx, G. W. A.; Krooshof, G. J. P.; Rijke, A. Process for the Separation of Formic Acid from Methyltetrahydrofuran. US 20160107975 A1, 2014.

(8) Glass, M.; Aigner, M.; Viell, J.; Jupke, A.; Mitsos, A. Liquid-Liquid Equilibrium of 2-Methyltetrahydrofuran/Water over Wide Temperature Range: Measurements and Rigorous Regression. Fluid Phase Equilib. 2017, 433, $212-225$. https://doi.org/10.1016/j.fluid.2016.11.004.

(9) Hirata, M.; Hirose, Y. Vapor-Liquid Equilibria of Ternary System Water-Acetic Acid-n-Butyl Acetate. Chem. Eng. 1966, 30 (2), 121128,a1. https://doi.org/10.1252/kakoronbunshu1953.30.121.

(10) Lladosa, E.; Montón, J. B.; Cruz Burguet, M.; Muñoz, R. Phase Equilibrium for the Esterification Reaction of Acetic Acid + Butan-1Ol at 101.3 KPa. J. Chem. Eng. Data 2008, 53 (1), 108-115. https://doi.org/10.1021/je700411p.

(11) Laitinen, A. T.; Penttilä, K. J. T.; Kaunisto, J. M. Physical Solvent Extraction of Levulinic Acid from Dilute Aqueous Solution with 2Methyltetrahydrofuran. Sep. Sci. Technol. 2016, 51 (3), 465-473. https://doi.org/10.1080/01496395.2015.1105264. 